\title{
Red Shoes
}

Erin Brannigan, University of New South Wales

Keywords: dance, screen, festivals, musicals, curation

My mother watched the musicals that came on television in the middle of the day in Australia in the 1970s. So we did too. She knew all the songs and sang along.

In 1999 at Monaco Dance Forum we were like the United Nations. I knew practically every dance screen curator in the world and we talked about how much we paid artists to screen their films. Nerdy dancefilm spotters. Alla Kovgan (Russia), Christiana Galanopoulou (Greece), Steve Jackman (UK), Katherine Smith (Canada), Nicolas Villodre (France), Douglas Rosenberg (USA), Deirdre Towers (USA), Janine Dykmeyer (The Netherlands), Silvina Szperling (Argentina), Lynette Kessler (USA) Hélène Lesterlin (USA), Fabio Bruschi (Italy), Marilena Riccio (Italy), Nuria Font (Spain), Eduardo Bonito (Brazil), Franz Patay (Austria), Pascale Moyse (UK), Virve Sutinen (Finland), Michel Bargues (France), Birgit Hauska and Rita Kramp (Germany), Chendra Effendy (Indonesia), Avi Feldman (Israel), Mariana Arteaga Vazquez (Mexico), Magne Antonsen (Norway), Ellen Bromberg (USA), and many, many more who conjured programs and events from very little ... some of them still do. And many of them were also filmmakers.

It's such a shame that Olivia Newton John couldn't dance.

I saw Chantal Akerman's One Day Pina Asked ... (1983) in Film Studies at Sydney University with Laleen Jayamanne. That was the start of something.

Someone moves self-consciously, or suspends a gesture. It's begun.

In 2010 the Australian dancescreen festival ReelDance, begun in 2000, folded and the Australia Council for the Arts put three years of their funding out to tender. The organization that won, blew it all on one exhibition. Nobody presents dancescreen in Australia anymore, except art galleries.

William Kentridge and Nick Cave make beautiful dance animations for galleries.

Jan Verbeek, Pascal Magnin, Philippe Decouflé, Pascal Baes, Anna Di Maninor, Miriam King, Cordelia Beresford, David Hinton, Thierry De Mey, Laura Taler, Shelley Love, Wim Vandekeybus, Miranda Pennell, Tracie Mitchell, Nic Sandiland, Katrina McPherson, Simon Ellis, Sue Healey, Antonin De Bemels, Clara van Gool, Annick Vroom, Sean O'Brien, Margie Medlin, Daniel Belton, Magali Charrier, Lutz Gregor, Walter Verdin, Gina Czarnecki, Christinn Whyte...

The International Journal of Screendance 10 (2019).

https://doi.org/10.18061/ijsd.v10i0.6822

(c) 2019 Brannigan. This article is published under a Creative Commons Attribution 4.0 International License (https://creativecommons.org/licenses/by/4.0/) 
When I walked out of the screening room after viewing Rize (2005), my internal body was in knots.

The move from film festivals to exhibitions was the right one-you have to follow the artists.

My dance teacher, Dorothy Cowie, was an old hoofer from the Tivoli in Sydney. We had to yell out songs from the top of our lungs while holding paper rainbows around our heads. We sang all the same songs my mother sang.

Claire Denis, Angelica Mesiti, David Rosetzky, Tacita Dean, Raul Ruiz, Robert Bresson, Chantal Akerman, Isaac Julien, Bill Viola, Daniel Crooks, Shaun Gladwell ...

We learnt how to dance from music videos. Pointy shoes, spikey hair, and step touch side-to-side.

Amazing people convinced broadcasters to commission short dancefilms in the 1990s to screen on television. That doesn't happen anymore.

Bob Lockyer ...

I went to the Sydney Film Festival in 2018 and saw ten films of varying genres and lengths. Nine of them had dancing in them.

Choreography has expanded and circulates liberated from dancing. Cinema was an early site for this adventure.

\section{Biography}

Dr. Erin Brannigan is Senior Lecturer in Theatre and Performance at the University of New South Wales and works as a writer, academic and curator. Her academic publications include Moving Across Disciplines: Dance in the Twenty-First Century (Sydney: Currency House, 2010), Dancefilm: Choreography and the Moving Image (New York: Oxford University Press, 2011) and Bodies of Thought: 12 Australian Choreographers, co-edited with Virginia Baxter (Kent Town: Wakefield Press, 2014). She has published various chapters and articles in film, performance and dance journals and anthologies. Her current research projects are The Persistence of Dance: Choreography, Art and Experimental Composition (a monograph), New Paradigms for Performance Pedagogies (UNSW T\&L Grant with Bryoni Trezise) and Dancing Sydney : Mapping Movement : Performing Histories (Linkage project with Julie-Anne Long and Amanda Card).

Email: e.brannigan@unsw.edu.au

Website: cargocollective.com/Erinbrannigan 


\section{References}

One Day Pina Asked .... Dir. Chantel Akerman. Film. 1983. Icarus.

Rize. Dir. David LaChapelle. Film. 2005. Lionsgate. 